\title{
Pengaruh Kepuasan Kerja Dan Disiplin Kerja Terhadap Kinerja Karyawan Pada Bank Rakyat Indonesia Cabang Putri Hijau Medan
}

\author{
Mutia Arda \\ Dosen Fakultas Ekonomi dan Bisnis, Universitas Muhammadiyah Sumatera Utara \\ Email: mutiaarda16@gmail.com
}

\begin{abstract}
ABSTRAK
Tujuan penelitian ini adalah untuk menganalisis pengaruh kepuasan kerja dan disiplin karyawan terhadap kinerja kerja Bank Rakyat Indonesia Cabang Putri Hijau Medan.

Jenis penelitian ini bersifat asosiatif. Populasi penelitian ini adalah seluruh karyawan di departemen pemasaran Bank Rakyat Indonesia Cabang Putri Hijau Medan sebanyak 31 karyawan dan semua menjadi sampel. Penelitian ini menggunakan metode sensus atau sampel jenuh. Metode pengumpulan data penelitian ini adalah kuesioner, wawancara, dan dokumentasi. Metode analisis data menggunakan analisis deskriptif dan regresi linier berganda. Hasil penelitian ini menunjukkan bahwa kepuasan kerja berpengaruh positif dan tidak signifikan terhadap kinerja karyawan, Disiplin memiliki pengaruh positif dan signifikan terhadap kinerja, sedangkan secara simultan kepuasan kerja dan disiplin kerja secara bersama-sama berpengaruh positif terhadap kinerja karyawan Bank Rakyat Indonesia Cabang Putri Hijau Medan. Disiplin pegawai memiliki pengaruh dominan terhadap kepuasan kerja. Koefisien determinasi (Adjusted R Square) adalah 0,162 artinya bahwa $16,2 \%$ variabel kinerja dapat dijelaskan dari kepuasan kerja dan disiplin karyawan sedangkan sebanyak $83,8 \%$ dapat dijelaskan oleh variabel lain dimana tidak diteliti oleh peneliti dalam penelitian ini.
\end{abstract}

Kata Kunci: Kepuasan kerja, disiplin,kinerja

\section{The Influence of Job Satisfaction and Work Discipline on Employee Performance at Bank Rakyat Indonesia Branch Putri HIjau Medan}

\begin{abstract}
The purpose of this study is to analyze the effect of job satisfaction and employee discipline on the work performance of Bank Rakyat Indonesia Branch Putri Hijau Medan. This type of research is associative. The population of this research is all employees in a marketing department of Bank Rakyat Indonesia Branch Putri Hijau Medan as many as 31 employees and all become sample. This research uses census method or saturated sample. Methods of data collection of this study are questionnaires, interviews, and documentation. Methods of data analysis using descriptive analysis and multiple linear regression. The results of this study indicate that job satisfaction has a positive and insignificant effect on employee performance, Discipline has the positive and significant influence on performance, while simultaneously job satisfaction and work discipline together positively influence to employee performance of Bank Rakyat Indonesia Branch of Putri Hijau Medan. Employee discipline has a dominant influence on job satisfaction. The coefficient of determination (Adjusted $R$ Square) is 0.162 means that $16.2 \%$ performance variables can be explained from job satisfaction and employee discipline while as much as $83.8 \%$ can be explained by other variables which are not examined by researchers in this study.
\end{abstract}

Keywords: Job Satisfaction, Employee Discipline, and Performance

How to cite:

Arda, M. (2017). Pengaruh Kepuasan Kerja Dan Disiplin Kerja Terhadap Kinerja Karyawan Pada Bank Rakyat Indonesia Cabang Putri Hijau Medan Jurnal Ilmiah Manajemen \& Bisnis, 18(1), 45-60. 


\section{PENDAHULUAN}

Sumber daya manusia merupakan faktor yang sangat menentukan kemajuan sebuah organisasi. Bahkan bisa dikatakan sumber daya manusia merupakan unsur terpenting disamping unsur lain, seperti modal, bahan baku, dan mesin. Tidak ada satu perusahaan yang dapat tumbuh dan berkembang tanpa unsur manusia dengan kemampuan manajerial dan moralitas kerja yang memadai. Hal ini sesuai dengan yang dikemukakan oleh Hasibuan (2006:12), yang menyatakan bahwa karyawan adalah kelayakan utama suatu perusahaan, karena tanpa keikutsertaan mereka, aktivitas perusahaan tidak akan terjadi. Karyawan berperan aktif dalam menetapkan rencana, sistem, proses dan tujuan yang ingin dicapai. Kinerja suatu perusahaan akan meningkat apabila terdapat kerjasama dan hubungan yang baik antara pimpinan dan karyawannya. Dengan meningkatkan kinerja karyawan akan meningkatkan kinerja perusahaan. Untuk itu karyawan sebaiknya diperlakukan sebagai partner usaha dan bukan sebagai pekerja semata.

Menurut Mangkunegara (2011:117) kepuasan kerja berhubungan dengan dimensi seperti turn over, tingkat absensi, umur, tingkat pekerjaan, dan ukuran organisasi perusahaan. Dimensi kepuasan kerja memiliki ukuran relatif sama antara satu organisasi dengan organisasi lainnya. Turn over sebagai dimensi yang paling akurat untuk merefleksikan apakah kepuasan kerja di suatu perusahaan tinggi atau rendah, kemudian diikuti oleh tingkat absensi, umur, tingkat pekerjaan dan ukuran organisasi pada tingkat terakhir.

Disiplin menurut Waridin dan Masrukhin (2006:77) sebagai keadaan ideal dalam mendukung pelaksanaan tugas sesuai aturan dalam rangka mendukung optimalisasi kerja. Salah satu syarat agar disiplin dapat ditumbuhkan dalam lingkungan kerja ialah, adanya pembagian kerja yang tuntas sampai kepada pegawai atau karyawan yang paling bawah, sehingga setiap orang tahu dan sadar apa tugasnya, bagaimana melakukannya, kapan pekerjaan dimulai dan selesai, seperti apa hasil kerja yang disyaratkan, dan kepada siapa mempertanggung jawabkan hasil pekerjaan itu. Untuk itu disiplin harus ditumbuh kembangkan agar tumbuh pula ketertiban dan efisiensi.

Karyawan Bank Rakyat Indonesia Cabang Putri Hijau Medan merupakan salah satu aset yang memegang peranan penting dalam perkembangan Bank Rakyat Indonesia Cabang Putri Hijau Medan. Karena dengan karyawan tersebut, kegiatan perusahaan dapat terlaksana dengan baik. Karena itu karyawan dituntut untuk berlaku disiplin dalam bekerja. Bank Rakyat Indonesia khususnya Cabang Putri Hijau Medan membuat kebijakan - kebijakan yang harus dipatuhi para karyawannya diantaranya karyawan diwajibkan untuk mengikuti kegiatan doa bersama di pagi hari, briefing pagi dan karyawan yang melakukan fraud (kesalahan dalam kerja) harus bertanggung jawab atas tindakannya. Apabila karyawan tidak mematuhi kebijakan tersebut maka konsekuensinya adalah karyawan diberikan surat peringatan satu sampai dengan tahap selanjutnya. Selain itu, karyawan dilarang datang terlambat ke kantor ataupun alpha (tanpa keterangan). Karena sistem absensi yang ada di Bank Rakyat Indonesia menggunakan kartu ATM BRI yang terintegrasi dengan rekening gaji. Apabila karyawan datang terlambat ke kantor ataupun tidak hadir tanpa keterangan maka gaji karyawan tersebut akan langsung terpotong.

Bank Rakyat Indonesia Cabang Putri Hijau Medan dalam aktivitasnya berusaha untuk selalu menekankan kepada seluruh sumber daya manusianya untuk dapat mencapai kinerja yang baik, dimana manfaat dari kinerja tersebut tidak hanya dirasakan individu tetapi juga dirasakan oleh institusi yang bersangkutan. Bank Rakyat Indonesia 


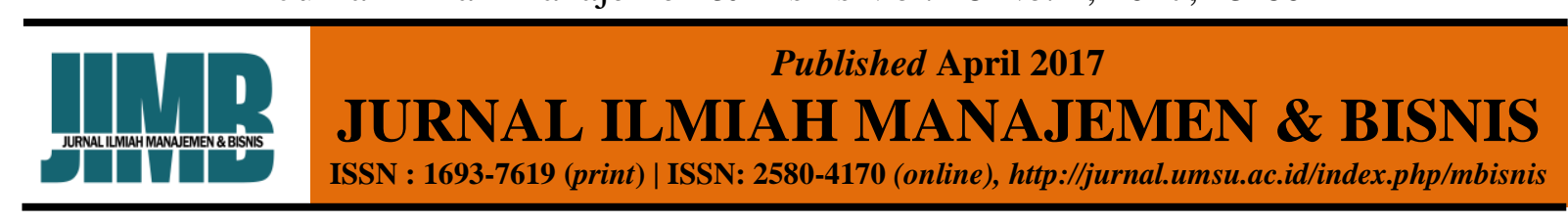

Cabang Putri Hijau Medan tidak luput dari ketidakpastian dalam menangani pelayanan terhadap konsumennya yang bervariasi. Untuk dapat memuaskan konsumennya maka Bank Rakyat Indonesia harus dapat memotivasi karyawannya agar kepuasan nasabah dapat tercapai dengan baik. Untuk itu Bank Rakyat Indonesia harus dapat memberikan kepuasan kerja terhadap karyawan yang berdampak kepada peningkatan kinerja karyawan.

Namun dibalik semua itu, masih ada kekurangan-kekurangan yang terjadi dalam perusahaan. Beberapa karyawan merasa kondisi pekerjaan yang kurang memuaskan terlihat dari beban pekerjaan yang mereka laksanakan cukup besar, hal tersebut dapat dilihat dari penambahan jam kerja (lembur) yang dirasakan karyawan berakibat kepada kejenuhan karyawan dalam bekerja. Menurut peraturan yang ada di Bank Rakyat Indonesia Cabang Putri Hijau Medan, jam kerja di perusahaan mulai pukul 08.00 WIB sampai dengan 17.00 WIB. Namun pada kenyataannya masih terdapat karyawan yang bekerja diluar dari jam kerja. Berikut ini adalah jumlah karyawan lembur pada Bank Rakyat Indonesia Cabang Putri Hijau akan ditampilkan pada Tabel berikut:

Tabel 1. Jumlah Karyawan yang Lembur

\begin{tabular}{|c|c|c|c|}
\hline No & Tahun & $\begin{array}{c}\text { Jumlah } \\
\text { Karyawan } \\
\text { Lembur }\end{array}$ & $\begin{array}{c}\text { Persentase } \\
\text { Kenaikan } \\
\text { Per } \\
\text { Tahun }\end{array}$ \\
\hline 1 & 2013 & 107 orang & - \\
\hline 2 & 2014 & 120 orang & $12,15 \%$ \\
\hline 3 & 2015 & 123 orang & $2,5 \%$ \\
\hline 4 & 2016 & 135 orang & $9,76 \%$ \\
\hline \multicolumn{2}{|c|}{ Rata-rata } & 121,25 orang & $8,14 \%$ \\
\hline
\end{tabular}

Sumber: Bagian SDM BRI Cabang Putri Hijau Medan (2016), diolah

Berdasarkan Tabel 1 dapat kita lihat bahwa jumlah karyawan yang lembur dari tahun 2013 sampai tahun 2016 mengalami peningkatan, dengan rata-rata 121 karyawan setiap tahunnya,atau bila dipersentasekan kenaikan jumlah karyawan yang lemburper tahun sebesar $8,14 \%$. Berdasarkan hasil pengamatan dan wawancara, hal tersebut terjadi karena karyawan harus segera menyelesaikan tugasnya pada hari tersebut untuk menyiapkan laporan harian kerja. Selain itu, adanya tugas tambahan yang dimulai pada bulan September 2016 sampai dengan sekarang yang mewajibkan beberapa staf / karyawan untuk bekerja setiap hari untuk melayani nasabah khususnya menangani transaksi PT. Pelindo.

Untuk meningkatkan produktivitas perusahaan, pihak Bank Rakyat Indonesia Cabang Putri Hijau menambah jumlah karyawan pada beberapa divisi dan memberhentikan karyawan yang tidak dapat bekerja memenuhi target perusahaan. Menurut hasil wawancara dengan bagian personalia Bank Rakyat Indonesia Cabang Putri Hijau Medan, ditemukan satu orang yang karyawan yang mengundurkan diri pada bulan April 2016, dan empat orang diberhentikan karena tidak dapat mencapai target (putus kontrak). Pada tahun 2016, perusahaan merekrut 34 orang tenaga kerja baru, sehingga total tenaga kerja 197 karyawan. Perekrutan tersebut berlanjut sampai dengan April 2017, sekarang jumlah total tenaga kerja 220 orang. Hal tersebut dapat kita lihat dengan perhitungan sebagai berikut :

\section{Persentase Perputaran Tenaga Kerja $(\%)=$ \\ Jumlah Pekerja Keluar/masuk Periode Tertentu x $100 \%$ Jumlah Tenaga Kerja per periode}

Berikut ini adalah turnover karyawan dari Januari - Desember 2016. 


\section{iㅔ

Disiplin kerja merupakan variabel pendukung lain dalam kinerja karyawan. Bank Rakyat Indonesia Cabang Putri Hijau memakai sistem online yang terintegrasi dengan gaji karyawan untuk melakukan perhitungan absensi. Persentase tingkat absensi karyawan adalah sebagai berikut:

Persentase Tingkat Absensi $(\%)=$

\section{Jlh Karyawan yang tidak hadir x 100\% Jlh Karyawan Keseluruhan}

Setelah melakukan perhitungan yang dimulai dari bulan Januari sampai dengan Desember selama tahun 2016 maka diperoleh hasil perhitungan yang terlihat pada Tabel 3.

Tabel 3. Ketidakhadiran Karyawan Bank Rakyat Indonesia Cabang Putri Hijau Medan Periode Januari - Desember 2016

\begin{tabular}{|c|c|c|c|c|c|c|c|}
\hline \multirow{2}{*}{ Bln } & \multicolumn{6}{|c|}{ Alasan Ketidakhadiran } & \multirow{2}{*}{$\begin{array}{c}\text { Standar } \\
\text { Kritis } \\
\text { Absensi }\end{array}$} \\
\hline & $\mathbf{S}$ & $\%$ & I & $\%$ & $\mathbf{A}$ & $\%$ & \\
\hline 1 & 3 & 1,60 & 7 & 3,74 & - & - & \multirow{13}{*}{$3 \%$} \\
\hline 2 & 1 & 0,53 & 3 & 1,60 & - & - & \\
\hline 3 & 4 & 2,13 & 1 & 0,53 & - & - & \\
\hline 4 & 2 & 1,07 & - & - & - & - & \\
\hline 5 & 3 & 1,60 & 2 & 1,06 & - & - & \\
\hline 6 & 5 & 2,67 & 5 & 2,67 & - & - & \\
\hline 7 & 2 & 1,07 & 3 & 1,60 & - & - & \\
\hline 8 & 7 & 3,86 & 2 & 1,06 & - & - & \\
\hline 9 & 3 & 1,60 & 4 & 2,13 & - & - & \\
\hline 10 & 1 & 0,53 & 6 & 3,20 & - & - & \\
\hline 11 & 4 & 2,13 & 7 & 3,74 & - & - & \\
\hline 12 & 6 & 3,20 & 9 & 4,81 & - & - & \\
\hline Rata & 41 & 21,92 & 49 & 26,20 & - & - & \\
\hline
\end{tabular}

Sumber: Bagian SDM BRI Cabang Putri Hijau Medan (2016), diolah

Tabel 3 menunjukkan rata-rata tingkat kehadiran karyawan Bank Rakyat Indonesia Cabang Putri Hijau periode Januari-Desember 2016 dengan keterangan (sakit) adalah sebanyak 41 orang dan keterangan (izin) adalah sebanyak 49 orang, atau bila dipersentasikan menjadi $21,92 \%$ dan $26,20 \%$ per tahun. Standar kritis ketidakhadiran sebesar 3\% yang telah ditetapkan oleh Bank Rakyat Indonesia Cabang Putri Hijau telah terlampaui. Dari data tersebut terlihat tingginya angka ketidakhadiran dengan alasan izin. Ketidakhadiran karyawan karena izin ini menunjukkan kurangnya kesadaran akan disiplin kerja. Berdasarkan hasil pengamatan dan wawancara yang telah dilakukan, hal tersebut diduga terjadi karena karyawan sulit mendapatkan cuti. Akibatnya banyak diantara mereka memakai alasan izin ataupun sakit agar tidak dikenakan potongan langsung gaji yang besar karena alpha (tanpa keterangan). Jika hal ini terus berkelanjutan akan berdampak pada kinerja perusahaan secara keseluruhan, karena kehadiran karyawan berkaitan dengan produktivitas yang dicapai perusahaan.

Kinerja Bank Rakyat Indonesia Cabang Putri Hijau Medan untuk tahun 2016 secara umum mengalami penurunan, khususnya karyawan bagian pemasaran (Account Officer dan Funding Officer) pada tahun 2016. Untuk mengetahui seberapa besar pencapaian target perusahaan pada bagian pemasaran, Bank Rakyat Indonesia Cabang Putri Hijau Medan sendiri memiliki target dengan tingkat realisasi yang ditampilkan pada Tabel 4. 


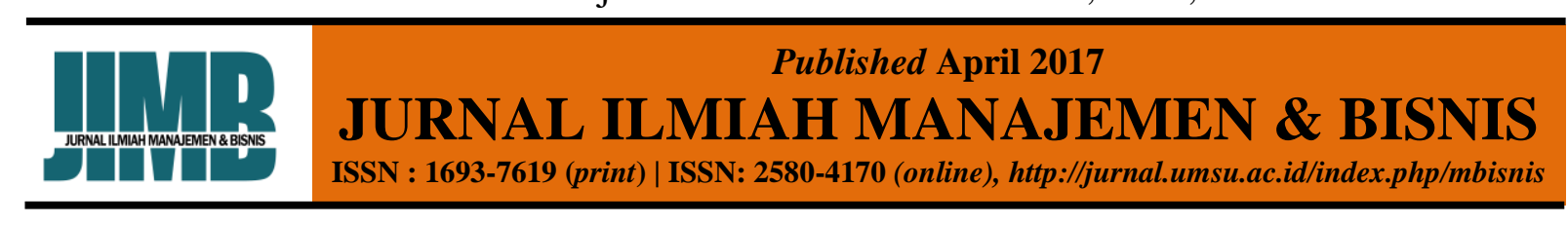

Tabel 4. Target Penjualan Jasa Simpanan dan Pinjaman

Periode Januari - Desember 2016 (Rp.000.000,-)

\begin{tabular}{|c|c|c|c|c|c|c|}
\hline Bln & \multicolumn{3}{|c|}{ Simpanan } & \multicolumn{3}{c|}{ Pinjaman } \\
\hline & Target & Realisasi & Ket & Target & Realisasi & Ket \\
\hline 1 & 252.288 & 1.160 .453 & $\mathrm{~T}$ & $125.179,5$ & 835.663 & $\mathrm{~T}$ \\
\hline 2 & 504.575 & 1.986 .277 & $\mathrm{~T}$ & 250.359 & 989.781 & $\mathrm{~T}$ \\
\hline 3 & 756.863 & 2.088 .071 & $\mathrm{~T}$ & $375.538,5$ & 948.967 & $\mathrm{~T}$ \\
\hline 4 & 1.009 .150 & 1.863 .677 & $\mathrm{~T}$ & 500.718 & 1.033 .733 & $\mathrm{~T}$ \\
\hline 5 & 1.261 .438 & 1.750 .646 & $\mathrm{~T}$ & $625.897,5$ & 1.031 .567 & $\mathrm{~T}$ \\
\hline 6 & 1.513 .726 & 2.257 .725 & $\mathrm{~T}$ & 751.077 & 1.046 .831 & $\mathrm{~T}$ \\
\hline 7 & 1.766 .013 & 1.469 .659 & $\mathrm{TT}$ & $876.256,5$ & 1.068 .081 & $\mathrm{~T}$ \\
\hline 8 & 2.018 .301 & 1.725 .399 & $\mathrm{TT}$ & 1.001 .436 & 946.920 & $\mathrm{TT}$ \\
\hline 9 & 2.270 .588 & 1.791 .458 & $\mathrm{TT}$ & $1.126 .615,5$ & 1.043 .993 & $\mathrm{TT}$ \\
\hline 10 & 2.522 .876 & 1.649 .222 & $\mathrm{TT}$ & 1.251 .795 & 1.103 .128 & $\mathrm{TT}$ \\
\hline 11 & 2.775 .163 & 1.582 .762 & $\mathrm{TT}$ & $1.376 .974,5$ & 1.111 .028 & $\mathrm{TT}$ \\
\hline 12 & $\mathbf{3 . 0 2 7 . 4 5 1}$ & $\mathbf{1 . 9 9 8 . 3 8 5}$ & $\mathrm{TT}$ & $\mathbf{1 . 5 0 2 . 1 5 4}$ & $\mathbf{1 . 2 9 3 . 0 9 5}$ & $\mathrm{TT}$ \\
\hline
\end{tabular}

Sumber : Bagian Pemasaran BRI Cabang Putri Hijau Medan (2016), diolah

Dari Tabel 4 terlihat bahwa target simpanan sampai Desember tahun 2016 adalah Rp 3.027.451.000.000,- sementara dapat dilihat bahwa simpanan yang dapat direalisasikan sampai akhir tahun 2016 hanya Rp 1.998.385.000.000,- sedangkan target pinjaman sampai Desember tahun 2016 adalah $\mathrm{Rp}$ 1.502.154.000.000,sementara jumlah pinjaman yang dapat terealisasi sampai akhir tahun 2016 hanya Rp1.293.095.000.000,-. Hal ini menunjukkan kinerja karyawan dalam pencapaian target simpanan dan pinjaman masih belum dapat direalisasikan jika dilihat dari jumlah simpanan dan pinjaman sebab realisasi berada dibawah angka target.

\section{KAJIAN TEORI \\ Kepuasan Kerja}

Menurut Hasibuan (2006:202) kepuasan kerja adalah sikap emosional yang menyenangkan dan mencintai pekerjaannya. Sikap ini dicerminkan oleh moral kerja, kedisiplinan, dan prestasi kerja. Menurut Moh.As'ad dalam Sunyoto (2012:26) ; kepuasan kerja (job satisfaction) adalah keadaan emosional yang menyenangkan atau tidak menyenangkan dimana para karyawan memandang pekerjaannya.
Menurut Wexley dan Yukl dalam Sunyoto (2012:27) ada 3 macam teori kepuasan kerja yang lazim dikenal, yaitu :

1. Discrepancy Theory

Teori ini pertama kali dipelopori oleh Porter (1961). Ia mengukur kepuasan kerja seseorang dengan menghitung selisih antara apa yang seharusnya dengan kenyataan yang dirasakan. Kemudian Locke (1969) menerangkan bahwa kepuasan kerja seseorang tergantung pada discrepancy antara should be (expectation needs or value) dengan apa yang menurut perasaannya atau persepsinya telah diperoleh melalui pekerjaan. Menurut penelitian yang dilakukan Wanous dan Lawer (1972) yang dikutip dari Wexley dan Yukl, menemukan bahwa sikap karyawan terhadap pekerjaan tergantung bagaimana discrepancy itu dirasakannya.

2. Equity Theory

Equity theory dikembangkan oleh Adams tahun 1963. Pendahulu dari teori ini adalah Zalzenik tahun 1958 yang dikutip dari Locke (1969). Prinsip teori ini adalah bahwa orang akan merasa puas dan tidak puas, tergantung apakah ia merasakan adanya keadilan (equity). 
Perasaan equity dan inequity atas situasi, diperoleh orang dengan cara membandingkan dirinya dengan orang lain yang sekelas, sekantor dan pemerintah dipengaruhi oleh motivasi.

\section{Two Factor Theory}

Prinsip teori ini bahwa kepuasan kerja dan ketidakpuasan kerja merupakan dua hal yang berbeda, artinya kepuasan dan ketidakpuasan terhadap pekerjaan tidak merupakan variabel yang kontiniu. Teori ini pertama kali dikemukakan oleh Frederick Herzberg tahun 1959. Beliau membagi situasi yang mempengaruhi sikap seseorang terhadap pekerjaan menjadi dua kelompok yakni :

a. Satisfiers atau motivator adalah situasi yang membuktikannya sebagai kepuasan kerja, yang terdiri dari achievement, recognition, work itself, responsibility and advancement.

b. Dissatisfier (Hygiene Factors) adalah faktor-faktor yang terbukti menjadi sumber ketidakpuasan yang terdiri dari company policy and administration, supervision, technical, salary, interpersonal, relation, working condition, job security and status. Menurut teori ini perbaikan salary dan kondisi kerja tidak akan menghilangkan ketidakpuasan tetapi hanya mengurangi ketidakpuasan kerja. Selanjutnya Herzberg mengemukakan bahwa yang dapat memacu orang bekerja dengan baik dan bergairah hanyalah kelompok satisfiers.

Faktor-faktor / dimensi yang mempengaruhi kepuasan kerja menurut Sutrisno (2011:80) sebagai berikut :

1. Faktor psikologis

Merupakan faktor yang berhubungan dengan kejiwaan karyawan, yang meliputi minat, ketentraman dalam bekerja, sikap terhadap kerja, bakat, dan keterampilan.

\section{Faktor sosial}

Merupakan faktor yang berhubungan dengan interaksi sosial antar karyawan maupun karyawan dengan atasan dan lingkungan kerja karyawan.

3. Faktor fisik

Merupakan faktor yang berhubungan dengan kondisi fisik karyawan, meliputi jenis pekerjaan, pengaturan waktu dan waktu istirahat, perlengkapan kerja, keadaan ruangan, suhu, penerangan, pertukaran udara, kondisi kesehatan karyawan, umur, dan sebagainya.

4. Faktor finansial

Merupakan faktor yang berhubungan dengan jaminan serta kesejahteraan karyawan, yang meliputi sistem dan besarnya gaji, jaminan sosial, tunjangan, fasilitas yang diberikan, promosi jabatan dan sebagainya.

\section{Disiplin Kerja}

Disiplin kerja yang baik mencerminkan besarnya rasa tanggung jawab seseorang terhadap tugas-tugas yang diberikan kepadanya. Hal ini mendorong gairah kerja, semangat kerja dan terwujudnya tujuan organisasi, karyawan dan masyarakat. Oleh karena itu, setiap manajer selalu berusaha agar bawahannya mempunyai kedisiplinan yang baik. Seorang manajer dikatakan efektif dalam kepemimpinannya, jika para bawahannya berdisiplin baik. Kedisiplinan dapat diartikan bilamana karyawan selalu datang dan pulang tepat pada waktunya, mengerjakan semua pekerjaannya dengan baik, mematuhi semua peraturan perusahaan dan norma sosial yang berlaku (Fathoni, 2006:126).

Menurut Hasibuan (2006:194) ada 8 indikator kedisiplinan antara lain adalah :

1. Tujuan dan kemampuan

Tujuan yang akan dicapai harus jelas dan ditetapkan secara ideal serta cukup menantang bagi kemampuan karyawan. 
Hal ini berarti bahwa tujuan (pekerjaan) yang dibebankan kepada karyawan harus sesuai dengan kemampuan karyawan bersangkutan, agar dia bekerja sungguhsungguh dan disiplin dalam mengerjakannya.

2. Teladan pimpinan

Pimpinan dijadikan teladan dan panutan oleh para bawahannya. Pimpinan harus memberi contoh yang baik, berdisiplin baik, jujur, adil, serta sesuai kata dengan perbuatan. Dengan teladan pimpinan yang baik, kedisiplinan bawahan pun akan ikut baik. Jika teladan pimpinan kurang baik (kurang berdisiplin), para bawahan pun akan kurang disiplin.

3. Balas jasa

Balas jasa akan memberikan kepuasan dan kecintaan karyawan terhadap perusahaan/pekerjaannya. Semakin besar balas jasa semakin baik kedisiplinan karyawan. Karyawan sulit berdisiplin baik selama kebutuhan-kebutuhan primernya tidak terpenuhi dengan baik.

4. Keadilan

Keadilan yang dijadikan dasar kebijaksanaan dalam pemberian balas jasa (pengakuan) atau hukuman akan merangsang terciptanya kedisiplinan karyawan yang baik. Manajer yang cakap dalam memimpin selalu berusaha bersikap adil terhadap semua bawahannya. Dengan keadilan yang baik akan menciptakan kedisiplinan yang baik pula. Jadi, keadilan harus diterapkan dengan baik pada setiap perusahaan supaya kedisiplinan karyawan perusahaan baik pula.

5. Waskat

Waskat (pengawasan melekat) berarti atasan harus aktif dan langsung mengawasi perilaku, moral, sikap, gairah kerja, dan prestasi kerja bawahannya. Waskat efektif merangsang kedisiplinan dan moral kerja karyawan. Karyawan merasa mendapat perhatian, bimbingan, petunjuk, pengarahan, dan pengawasan dari atasannya.

6. Sanksi hukuman

Berat/ringannya sanksi hukuman yang akan diterapkan ikut mempengaruhi baik/buruknya kedisiplinan karyawan. Sanksi hukuman harus ditetapkan berdasarkan pertimbangan logis, masuk akal, dan diinformasikan secara jelas kepada semua karyawan. Sanksi hukuman hendaknya cukup wajar untuk setiap tingkatan yang indisipliner, bersifat mendidik, dan menjadi alat motivasi untuk memelihara kedisiplinan dalam perusahaan.

7. Ketegasan

Pimpinan harus berani dan tegas, bertindak untuk menghukum setiap karyawan yang indisipliner sesuai dengan sanksi yang telah ditetapkan. Pimpinan yang berani bertindak tegas menerapkan hukuman bagi karyawan yang indisipliner akan disegani dan diakui kepemimpinannya oleh bawahan.

8. Hubungan kemanusiaan

Hubungan-hubungan baik bersifat vertikal maupun horizontal yang terdiri dari direct single relationship, direct group relationship, dan cross relationship hendaknya harmonis. Terciptanya human relationship yang serasi akan mewujudkan lingkungan dan suasana kerja yang nyaman. Hal ini akan memotivasi kedisiplinan yang baik pada perusahaan. Jadi, kedisiplinan karyawan akan tercipta apabila hubungan kemanusiaan dalam organisasi tersebut baik.

\section{Kinerja Karyawan}

Dalam melaksanakan kerjanya, karyawan menghasilkan sesuatu yang disebut dengan kinerja. Kinerja adalah hasil kerja seseorang karyawan selama periode tertentu dibandingkan dengan berbagai kemungkinan misalnya standard, target/sasaran atau kriteria yang telah 


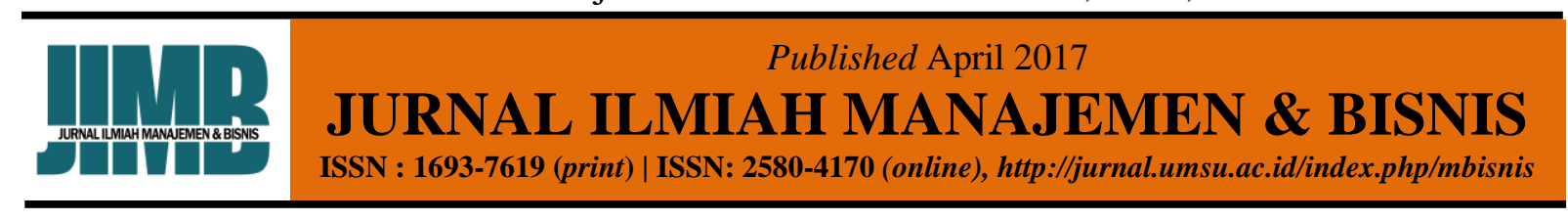

ditentukan terlebih dahulu dan disepakati bersama. Penilaian kinerja adalah kegiatan manajer untuk mengevaluasi perilaku prestasi kerja karyawan serta menetapkan kebijaksanaan selanjutnya (Hasibuan, 2006:87).

Menurut Edwin Flippo dalam Sunyoto (2012:22) indikator kinerja karyawan, yaitu:

1. Mutu kerja.

Mencerminkan peningkatan mutu dan standar kerja yang telah ditentukan sebelumnya, biasanya disertai dengan peningkatan kemampuan dan nilai ekonomi. Berkaitan dengan ketepatan waktu, keterampilan dan kepribadian dalam melakukan pekerjaan.

2. Kualitas kerja

Berkaitan dengan pemberian tugas-tugas tambahan yang diberikan atasan kepada bawahannya, prestasi kerja karyawan dan pencapaian target.

3. Ketangguhan

Berkaitan dengan tingkat kehadiran, ketaatan, pemberian waktu libur dan jadwal keterlambatan hadir di tempat kerja.

4. Sikap

Merupakan sikap yang ada pada karyawan yang menunjukkan seberapa jauh sikap tanggung jawab mereka terhadap sesama teman, dengan atasan dan seberapa jauh tingkat kerja sama dalam menyelesaikan pekerjaan. Hal ini juga berkaitan dengan cara karyawan bekerja sama dalam kelompok dan inisiatif karyawan dalam bekerja.

\section{Penelitian Terdahulu}

Napitupulu (2011) melakukan penelitian yang berjudul "Pengaruh Disiplin Kerja dan Komitmen Karyawan terhadap Prestasi Kerja Karyawan PT. Tonga Tiur Putra Medan". Penelitian tersebut bertujuan untuk mengetahui Pengaruh Disiplin Kerja $\left(\mathrm{X}_{1}\right)$ dan Komitmen Karyawan $\left(\mathrm{X}_{2}\right)$ terhadap Prestasi Kerja (Y) karyawan pada kantor PT. Tonga Tiur Medan. Dengan hipotesis Disiplin Kerja dan Komitmen Karyawan mempunyai pengaruh yang signifikan terhadap Prestasi Kerja karyawan pada PT. Tonga Tiur Medan. Penelitian ini merupakan jenis penelitian asosiatif dan yang menjadi sampel penelitian ini adalah 65 orang karyawan tetap pada PT. Tonga Tiur Medan. Metode analisis yang digunakan adalah metode analisis deskriptif dan statistik yang menggunakan alat analisis regresi berganda dan data diolah dengan program SPSS versi 17.00 yang terlebih dahulu diuji validitas dan realibilitasnya. Hasil penelitian ini menunjukkan bahwa variabel Disiplin Kerja $\left(\mathrm{X}_{1}\right)$ dan Komitmen Kerja $\left(\mathrm{X}_{2}\right)$ berpengaruh positif dan signifikan terhadap prestasi karyawan (Y) pegawai pada PT. Tonga Tiur Medan, artinya semakin baik disiplin kerja dan komitmen karyawan, maka prestasi kerja juga semakin tinggi. Koefisien determinan dari hasil analisis sebesar $22 \%$ sedangkan sisanya sebesar $78 \%$ dipengaruhi oleh faktor lain di luar kontribusi penelitian ini.

Teruna (2012) melakukan penelitian yang berjudul "Pengaruh Motivasi dan Kepuasan Kerja Terhadap Kinerja Karyawan Pada PT. Aplikasinusa Lintasarta Medan". Tujuan penelitian ini adalah untuk mengetahui Pengaruh Kepuasan Kerja Karyawan Terhadap Kinerja Karyawan Pada PT. Aplikasinusa Lintasarta Medan. Sampel yang digunakan dalam penelitian ini adalah sebanyak 68 responden yang digunakan dengan menggunakan teknik nonprobability sampling dengan teknik sampel jenuh. Analisis yang digunakan meliputi uji validitas, uji reliabilitas, uji t, korelasi sederhana, korelasi berganda dan uji determinasi. Metode pengumpulan data yang digunakan adalah dengan angket kuesioner. Hasil pengujian menunjukkan bahwa variabel motivasi kerja dan kepuasan kerja berpengaruh positif terhadap variabel kinerja karyawan. Hal ini dibuktikan dengan hasil perhitungan antara variabel motivasi terhadap kinerja bahwa nilai $t_{\text {hitung }}(2,167)>$ 
$t_{\text {tabel }}(2,050)$ dan antara variabel kepuasan kerja terhadap kinerja dengan nilai $t_{\text {hitung }}$ $(2,618)>t_{\text {tabel }}(2,050)$ sesuai dengan pengujian hipotesis bahwa jika nilai $t_{\text {hitung }} \geq$ $t_{\text {tabel }}$ maka pengujian hipotesis Ho ditolak, dan nilai korelasi berganda sebesar $(0,464)$, kemudian hasil uji $\mathrm{F}$ bahwa nilai $\mathrm{F}_{\text {hitung }}$ $(3,472)>F_{\text {tabel }}(3,340)$ sesuai dengan pengujian hipotesis bahwa jika $F_{\text {hitung }} \geq F_{\text {tabel }}$ maka pengujian hipotesis Ho ditolak, dengan demikian Ho ditolak yang menandakan bahwa variabel motivasi dan kepuasan kerja secara simultan dan signifikan berpengaruh terhadap variabel kinerja karyawan. Hasil analisis menggunakan koefisien determinasi diketahui bahwa 21,5 persen hasil variasi dari kinerja karyawan dapat dijelaskan oleh variabel bebas yang diteliti dalam penelitian ini dan 78,5 persen dijelaskan oleh faktorfaktor lain yang tidak dibahas pada penelitian ini.

\section{Kerangka Konseptual \\ Pengaruh Kepuasan Kerja Terhadap Kinerja Karyawan}

Secara ringkas dapat dikatakan bahwa pengaruh kepuasan kerja dengan kinerja karyawan adalah pernyataan : "Seorang pekerja yang bahagia adalah seorang pekerja yang produktif atau produktivitas menghasilkan kepuasan". Jika diterapkan dalam suatu organisasi maka dapat dikatakan organisasi dengan karyawan yang terpuasakan cenderung lebih efektif, sehingga produktivitas semakin meningkat (Robbins, 2008:114).

Menurut Gibson (2007:67) kepuasan kerja adalah sikap seseorang terhadap pekerjaan mereka, yang berpangkal dari aspek kerja, yaitu upah (gaji), kesempatan promosi serta faktor lingkungan kerja seperti gaya penyelia, kebijakan dan prosedur, kondisi kerja. Terdapat tiga pandangan tentang hubungan kepuasan dengan prestasi (satisfaction and job performance), yaitu : 1) Kepuasan kerja menimbulkan prestasi, 2) Prestasi menimbulkan kepuasan kerja, 3) Adanya unsur imbalan, tetapi tidak ada hubungan yang kuat.

Kepuasan kerja mencerminkan perasaan karyawan terhadap pekerjaanya yang tampak dalam sikap positif karyawan terhadap pekerjaanya yang dapat meningkatkan kinerja karyawan tersebut, sedangkan karyawan yang tidak memperoleh kepuasan kerja akan menimbulkan sikap agresif, atau sebaliknyaakan menunjukkan sikap menarik diri dari kontak dengan lingkungan sosialnya, (Sutrisno, 2011:80). Seorang karyawan akan merasa puas dalam kerja apabila tidak terdapat perbedaan atau selisih antara apa yang dikehendaki karyawan, dengan kenyataan yang mereka rasakan.

\section{Pengaruh Disiplin Kerja Terhadap Kinerja Karyawan}

Pentingnya peranan disiplin kerja terhadap kinerja/produktivitas karyawan dikemukakan oleh Musanef (2002:116) yang berpendapat bahwa : "Disiplin juga tidak kalah pentingnya dengan prinsipprinsip yang lainnya, artinya disiplin setiap pegawai selalu mempengaruhi hasil prestasi kerja. Oleh sebab itu dalam setiap organisasi perlu ditegaskan disiplin pegawaipegawainya. Melalui disiplin yang tinggi produktivitas kerja pegawai pada pokoknya dapat ditingkatkan. Oleh sebab itu perlu ditanamkan kepada setiap pegawai disiplin yang sebaik - baiknya".

Kedisiplinan adalah salah satu faktor yang penting dalam suatu organisasi. Dikatakan sebagai faktor yang penting karena disiplin akan mempengaruhi kinerja karyawan dalam organisasi. Semakin tinggi disiplin karyawan, semakin tinggi prestasi kerja yang dapat dicapai. Pada umumnya disiplin yang baik apabila karyawan selalu datang dan pulang tepat pada waktunya, mengerjakan semua pekerjaannya dengan baik dan mematuhi semua peraturan 
perusahaan dan norma-norma sosial yang berlaku. Maka karyawan tersebut akan menghasilkan jumlah dan kualitas pekerjaan (kinerja) yang memuaskan. Disiplin adalah kesadaran sikap seseorang yang secara sukarela menaati semua peraturan dan sadar akan tugas dan tanggung jawabnya (Hasibuan, 2006:193). Jadi seseorang akan mematuhi / mengerjakan semua tugasnya dengan baik, bukan atas paksaan dan kesedihan.

\section{Pengaruh Kepuasan Kerja dan Disiplin Kerja Terhadap Kinerja Karyawan}

Pengaruh kepuasan kerja, disiplin kerja dan kinerja karyawan adalah kepuasan kerja mempengaruhi tingkat kedisiplinan dan kinerja karyawan, artinya jika kepuasan diperoleh dari pekerjaan maka kedisiplinan dan prestasi karyawan baik. Sebaliknya jika kepuasan kerja kurang tercapai dari pekerjaanya maka kedisiplinan dan prestasi karyawan rendah (Hasibuan, 2006:203).

Kinerja adalah sesuatu hasil kerja yang dicapai oleh seseorang karyawan dalam menyelesaikan pekerjaan yang dibebankan kepadanya, Sunyoto (2012:18). Kinerja karyawan merupakan perwujutan dari seberapa banyak mereka memberi kontribusi kepada organisasi. Oleh karena itu, penilaian kinerja sangat perlu dilakukan oleh perusahaan untuk mengetahui sejauh mana karyawan mampu berperan dalam perkembangan dan pertumbuhan perusahaan.

Secara sederhana kerangka konseptual dapat digambarkan sebagai berikut :

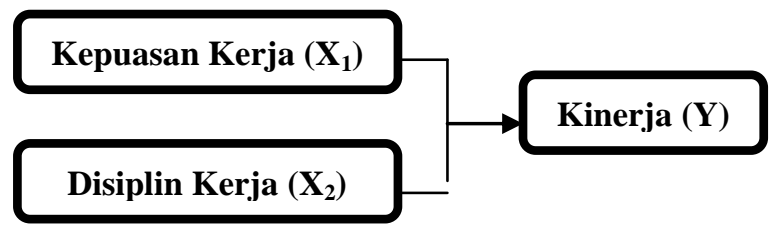

Sumber : Sutrisno (2011:80), Hasibuan (2006:194), dan Sunyoto (2012:22)

Gambar 2. Kerangka Konseptual.

Hipotesis adalah dugaan yang sifatnya sementara terhadap rumusan masalah penelitian. Oleh karena itu rumusan masalah penelitian biasanya disusun dalam bentuk kalimat pertanyaan (Sugiyono, 2006:306).

\section{METODE \\ Defenisi Operasional}

Defenisi operasional variabel akan menuntun peneliti untuk memenuhi unsur penelitian yang memberitahukan bagaimana caranya mengukur suatu variabel. Operasional variabel dalam penelitian ini adalah :

1. Kepuasan Kerja $\left(\mathrm{X}_{1}\right)$

Kepuasan kerja adalah sikap umum karyawan Bank Rakyat Indonesia Cabang Putri Hijau Medan terhadap pekerjaanya, yang menunjukkan perbedaan antara jumlah penghargaan yang diterima karyawan dan jumlah yang mereka yakini seharusnya mereka terima.

2. Disiplin Kerja $\left(X_{2}\right)$

Disiplin kerja adalah kesadaran sikap seseorang karyawan Bank Rakyat Indonesia Cabang Putri Hijau Medan yang secara sukarela menaati semua peraturan dan sadar akan tugas dan tanggung jawabnya.

3. Kinerja Keryawan (Y)

Kinerja adalah sesuatu hasil kerja yang dicapai oleh seseorang karyawan Bank Rakyat Indonesia Cabang Putri Hijau Medan dalam menyelesaikan pekerjaan yang dibebankan kepadanya.

\section{Skala Pengukuran Variabel}

Pengukuran yang digunakan oleh penulis untuk mengetahui masing-masing variabel yaitu variabel $\mathrm{X}_{1}$ (kepuasan kerja), $\mathrm{X}_{2}$ (disiplin kerja) dan variabel $\mathrm{Y}$ (kinerja karyawan) adalah Skala Likert. Skala likert digunakan untuk mengukur sikap, pendapat dan persepsi seseorang / kelompok tentang fenomena sosial. (Sugiyono, 2006:86).

Untuk keperluan analisis kuantitatif penelitian ini, maka setiap pertanyaan akan diberi skala sangat setuju sampai sangat tidak setuju. Skala likert menggunakan 5 
(lima) tingkatan jawaban yang dapat dilihat dari Tabel 3.2

Tabel 3.2

Instrumen Skala Likert

\begin{tabular}{|l|l|l|}
\hline No & \multicolumn{1}{|c|}{ Pertanyaan } & \multicolumn{1}{|c|}{ Skor } \\
\hline 1 & Sangat Setuju (SS) & 5 \\
\hline 2 & Setuju (S) & 4 \\
\hline 3 & Kurang Setuju (ST) & 3 \\
\hline 4 & Tidak Setuju (TS) & 2 \\
\hline 5 & $\begin{array}{l}\text { Sangat Tidak Setuju } \\
\text { (STS) }\end{array}$ & 1 \\
\hline
\end{tabular}

Sumber : Sugiyono $(2006: 86)$

\section{Populasi dan Sampel Penelitian}

Populasi pada penelitian ini adalah seluruh karyawan bagian pemasaran (Account Officer dan Funding Officer) pada Bank Rakyat Indonesia Cabang Putri Hijau Medan, yang berjumlah 31 orang.

Sampel adalah bagian dari jumlah dan karakteristik yang dimiliki oleh suatu populasi. Teknik pengambilan sampel dalam penelitian ini adalah sampel jenuh atau sensus. Sampling jenuh adalah teknik penentuan sampel bila semua anggota populasi digunakan sebagai sampel. Jadi sampel dalam penelitian ini adalah semua karyawan bagian pemasaran (Account Officer dan Funding Officer) pada Bank Rakyat Indonesia Cabang Putri Hijau Medan.

\section{Teknik Analisis}

\section{Metode Analisis Deskriptif}

Teknik analisis deskriptif merupakan teknik analisis data dimana peneliti mengelompokkan atau memisahkan komponen atau bagian yang relevan dari keseluruhan data serta merupakan salah satu bentuk analisis untuk menjadikan data mudah dikelola (Kuncoro, 2009:192).

Metode analisis deskriptif merupakan cara merumuskan dan menafsirkan data yang ada sehingga memberikan gambaran yang jelas melalui pengumpulan, penyusunan, dan penganalisisan data sehingga dapat diketahui gambaran data penelitian yang sedang diteliti.

\section{Uji Normalitas data}

Tujuan uji normalisasi adalah untuk mengetahui apakah distribusi sebuah data mengikuti atau mendekati distribusi normal. Uji normalitas dilakukan dengan pendekatan grafik dengan menggunakan tingkat signifikansi 5\%. Jika nilai Asyimp.Sig (2tailed) lebih besar dari 5\% artinya data variabel berdistribusi normal (Situmorang et $a l, 2011: 100)$.

\section{Uji Heterokedastisitas}

Uji heterokedastisitas berarti varians variabel independen adalah konstan atau sama untuk setiap nilai tertentu variabel independen (homokedastisitas). Model regresi yang baik adalah tidak terjadi heterokedastisitas diuji dengan menggunakan uji Glejser dengan pengambilan keputusan jika variabel independen signifikan secara statistik mempengaruhi variabel dependen, maka ada indikasi terjadi heterokedastisitas. Jika probabilitas signifikannya diatas tingkat kepercayaan 5\% dapat disimpulkan model regresi tidak mengarah adanya heterokedastisitas (Situmorang et al, 2011:107).

\section{Uji Multikolinearitas}

Uji multikolinearitas variabel independen yang satu dengan yang lain dalam model regresi berganda tidak saling berhubungan secara sempurna atau mendekati sempurna. Untuk mengetahui ada tidaknya gejala multikolinearitas dapat dilihat dari besarnya nilai Tolerance dan VIF (Variance Inflation Factor) melalui program SPSS.

Tolerance mengukur variabelitas variabel terpilih yang tidak dijelaskan oleh variabel independen lainnya. Nilai umumnya yang biasa dipakai adalah nilai 
Tolerance $>0,1$ atau nilai VIF $<5$, maka tidak terjadi multikolinearitas (Situmorang et al, 2011:133).

\section{Analisis Regresi Linier Berganda}

Analisis ini digunakan untuk mengetahui seberapa besar pengaruh variabel terikat. Metode regresi berganda dirumuskan sebagai berikut :

$$
\begin{array}{ll}
\mathbf{Y}=\mathbf{a}+ & \mathbf{b}_{\mathbf{1}} \mathbf{X}_{\mathbf{1}}+\mathbf{b}_{\mathbf{2}} \mathbf{X}_{\mathbf{2}}+\mathbf{e} \\
\text { Dimana } & \text { : } \\
\mathrm{Y} & =\text { kinerja karyawan } \\
\mathrm{a} & =\text { konstanta } \\
\mathrm{b}_{1}, \mathrm{~b}_{2} & =\text { koefisien regresi berganda } \\
\mathrm{X}_{1} & =\text { kepuasan kerja } \\
\mathrm{X}_{2} & =\text { disiplin kerja } \\
\mathrm{e} & =\text { standart error }
\end{array}
$$

\section{Uji Signifikasi Simultan (uji-F)}

Uji-F pada dasarnya menunjukkan apakah semua variabel bebas yang dimasukkan dalam model mempunyai pengaruh secara bersama-sama terhadap variabel terikat. $\mathrm{H}_{0}: \mathrm{b}_{1}=\mathrm{b}_{2}=0$, artinya secara bersama-sama tidak terdapat pengaruh yang positif dan signifikan dari variabel bebas $\left(\mathrm{X}_{1}\right.$, dan $\left.\mathrm{X}_{2}\right)$ yaitu berupa kepuasan kerja dan disiplin kerja terhadap kinerja karyawan sebagai variabel terikat (Y).

$\mathrm{H}_{1}: \mathrm{b}_{1} \neq \mathrm{b}_{2} \neq 0$, artinya secara bersama-sama terdapat pengaruh yang positif dan signifikan dari variabel bebas $\left(\mathrm{X}_{1}\right.$, dan $\left.\mathrm{X}_{2}\right)$ yaitu berupa kepuasan kerja dan disiplin kerja terhadap kinerja karyawan sebagai variabel terikat (Y). Kriteria pengambilan keputusan :

$\mathrm{H}_{0}$ diterima jika $\mathrm{F}_{\text {hitung }}<\mathrm{F}_{\text {tabel }} \alpha=5 \%$

$\mathrm{H}_{1}$ diterima jika $\mathrm{F}_{\text {hitung }}>\mathrm{F}_{\text {tabel }} \alpha=5 \%$

\section{Signifikasi Parsial (uji-t)}

Uji-t menunjukkan seberapa besar pengaruh variabel secara individual terhadap variabel terikat. $\mathrm{H}_{0}: \mathrm{b}_{1}=\mathrm{b}_{2}=0$, artinya secara parsial tidak terdapat pengaruh yang positif dan signifikan dari variabel bebas $\left(\mathrm{X}_{1}\right.$, dan $\left.\mathrm{X}_{2}\right)$ yaitu berupa kepuasan kerja dan disiplin kerja terhadap kinerja karyawan sebagai variabel terikat (Y).
$\mathrm{H}_{1}: \mathrm{b}_{1} \neq \mathrm{b}_{2} \neq 0$, artinya secara parsial terdapat pengaruh yang positif dan signifikan dari variabel bebas $\left(\mathrm{X}_{1}\right.$, dan $\left.\mathrm{X}_{2}\right)$ yaitu berupa kepuasan kerja dan disiplin kerja terhadap kinerja karyawan sebagai variabel terikat (Y). Kriteria pengambilan keputusan :

$\mathrm{H}_{0}$ diterima jika $\mathrm{t}_{\text {hitung }}<\mathrm{t}_{\text {tabel }} \alpha=5 \%$

$\mathrm{H}_{1}$ diterima jika $\mathrm{t}_{\text {hitung }}>\mathrm{t}_{\text {tabel }} \alpha=5 \%$

\section{Koefisien Determinasi $\left(\mathbf{R}^{2}\right)$}

Koefisien determinasi $\left(\mathrm{R}^{2}\right)$ pada intinya mengukur seberapa kemampuan model dalam menerangkan variabel terikat. Jika $\mathrm{R}^{2}$ semakin besar (mendekati satu), maka dapat dikatakan bahwa hubungan variabel bebas $\left(\mathrm{X}_{1}\right.$ dan $\left.\mathrm{X}_{2}\right)$ adalah besar terhadap variabel terikat (Y). Hal ini berarti model yang digunakan semakin kuat untuk menerangkan hubungan variabel bebas yang diteliti terhadap variabel terikat. Sebaliknya, jika $\mathrm{R}^{2}$ semakin kecil (mendekati nol) maka dapat dikatakan bahwa hubungan variabel bebas $\left(\mathrm{X}_{1}\right.$ dan $\left.\mathrm{X}_{2}\right)$ terhadap variabel terikat (Y) semakin kecil. Hal ini berarti model yang digunakan tidak kuat. Secara umum dapat dikatakan besarnya koefisien determinasi berganda $\left(\mathrm{R}^{2}\right)$ berada diantara 0 dan 1 atau $0 \leq \mathrm{R}^{2} \leq 1$.

\section{Pembahasan}

\section{Pengaruh Kepuasan Kerja Terhadap Kinerja Karyawan Bank Rakyat Indonesia Cabang Putri Hijau Medan}

Hasil penelitian menunjukkan bahwa kepuasan kerja positif dan tidak signifikan berpengaruh terhadap kinerja karyawan Bank Rakyat Indonesia Cabang Putri Hijau Medan. Hal ini terlihat dari nilai signifikansi 0,477 lebih besar dari 0,05 . Nilai $t$ hitung $(0,721)<\mathrm{t}$ tabel $(2,042)$ yang artinya walaupun ditingkatkan variabel kepuasan kerja sebesar satu satuan maka kinerja karyawan (Y) tidak akan meningkat sebesar 0,062 satuan.

Berdasarkan distribusi jawaban responden terhadap variabel kepuasan kerja 
diketahui bahwa jawaban dominan setuju pada pernyataan 5 sebesar $77,4 \%$ (Saya memperoleh jaminan keamanan lingkungan kerja yang diberikan perusahaan). Selain itu pernyataan setuju juga terlihat jelas pada pernyataan 3 sebesar 71,0 (Interaksi saya dengan atasan dalam menyelesaikan pekerjaan cukup baik). Dari keterangan tersebut dapat dijelaskan bahwa indikatorindikator kepuasan kerja yakni keamanan lingkungan kerja dan interaksi karyawan dengan atasannya pada Bank Rakyat Indonesia Cabang Putri Hijau Medan sudah diterapkan dengan baik, sehingga menimbulkan kepuasan karyawan dalam bekerja yang dapat dilihat dari turn over yang ada pada perusahaan tersebut rendah. Hal ini terlihat pada pendahuluan sebelumnya yang menjelaskan kepuasan kerja yang terjadi pada Bank Rakyat Indonesia Cabang Putri Hijau Medan berdasarkan hasil pengamatan, dokumentasi dan wawancara yang telah dilakukan. Locke dalam Wijono (2011:98) berpendapat bahwa kepuasan kerja sebagai suatu tingkat emosi yang positif dan menyenangkan individu. Kepuasan kerja adalah suatu hasil perkiraan individu terhadap pekerjaan atau pengalaman positif dan menyenangkan dirinya.

Walaupun kepuasan kerja berpengaruh tidak signifikan perusahaan selalu mengupayakan untuk meningkatkan kepuasan kerja karyawan agar dapat memperoleh hasil yang maksimal. "Seorang pekerja yang bahagia adalah seorang pekerja yang produktif atau produktivitas menghasilkan kepuasan". Jika diterapkan dalam suatu organisasi maka dapat dikatakan organisasi dengan karyawan yang terpuasakan cenderung lebih efektif, sehingga produktivitas semakin meningkat (Robbins, 2008:114).

Hasil penelitian ini juga didukung dengan penelitian terdahulu yang dilakukan Teruna (2012) melakukan penelitian yang berjudul "Pengaruh Motivasi dan Kepuasan
Kerja Terhadap Kinerja Karyawan Pada PT. Aplikasinusa Lintasarta Medan" yang menyatakan variabel motivasi kerja dan kepuasan kerja berpengaruh positif terhadap variabel kinerja karyawan.

\section{Pengaruh Disiplin Kerja Terhadap Kinerja Karyawan Bank Rakyat Indonesia Cabang Putri Hijau Medan}

Hasil penelitian secara serentak menunjukkan bahwa kepuasan kerja berpengaruh positif dan signifikan terhadap kinerja karyawan Bank Rakyat Indonesia Cabang Putri Hijau Medan. Hal ini terlihat dari nilai signifikansi 0,011 lebih kecil dari 0,05 . Nilai $\mathrm{t}$ hitung $(2,74)>\mathrm{t}$ tabel $(2,042)$ artinya jika ditingkatkan variabel disiplin kerja sebesar satu satuan maka kinerja karyawan (Y) akan meningkat sebesar 0,311 satuan.

Berdasarkan distribusi jawaban responden terhadap variabel disiplin kerja bahwa persentase setuju terlihat cukup besar yang terdapat pada pernyataan 17 sebesar $80,6 \%$ (Saya dapat bekerja dengan kelompok kerja saya dengan baik). Pada pernyataan 16 sebesar 74,2\% (Pimpinan saya sering memberikan peringatan/teguran). Berdasarkan hasil wawancara yang dilakukan, ini diduga terjadi karena sejak mulai tahun 2012 karyawan bagian pemasaran Bank Rakyat Indonesia Cabang Putri Hijau dituntut untuk mencapai target kerja yang lebih besar dibanding tahun sebelumnya sehingga para karyawan harus pandai bekerja dengan kelompok kerjanya agar mendapat hasil yang maksimal.

Pentingnya peranan disiplin kerja terhadap kinerja/produktivitas karyawan dikemukakan oleh Musanef (2002:116) yang berpendapat bahwa : "Disiplin juga tidak kalah pentingnya dengan prinsipprinsip yang lainnya, artinya disiplin setiap pegawai selalu mempengaruhi hasil prestasi kerja. Oleh sebab itu dalam setiap organisasi perlu ditegaskan disiplin pegawai- 
pegawainya. Melalui disiplin yang tinggi produktivitas kerja pegawai pada pokoknya dapat ditingkatkan. Oleh sebab itu perlu ditanamkan kepada setiap pegawai disiplin yang sebaik-baiknya".

Hasil penelitian ini juga didukung dan sejalan dengan penelitian terdahulu yang dilakukan Napitupulu (2011) melakukan penelitian yang berjudul "Pengaruh Disiplin Kerja dan Komitmen Karyawan terhadap Prestasi Kerja Karyawan PT. Tonga Tiur Putra Medan". Hasil penelitian ini menunjukkan bahwa variabel Disiplin Kerja $\left(\mathrm{X}_{1}\right)$ dan Komitmen Kerja $\left(\mathrm{X}_{2}\right)$ berpengaruh positif dan signifikan terhadap prestasi karyawan (Y) pegawai pada PT. Tonga Tiur Medan, artinya semakin baik disiplin kerja dan komitmen karyawan, maka prestasi kerja juga semakin tinggi.

\section{Pengaruh Kepuasan Kerja dan Disiplin Kerja Terhadap Kinerja Karyawan Bank Rakyat Indonesia Cabang Putri Hijau Medan}

Hasil penelitian menunjukkan adanya pengaruh yang positif antara variabel kepuasan kerja dan disiplin kerja terhadap kinerja karyawan Bank Rakyat Indonesia Cabang Putri Hijau Medan. Hal ini terlihat dari Sig yang lebih kecil dari alpha $\quad(0,032<0.05)$, berarti koefisien signifikan secara statistik, kepuasan kerja dan disiplin kerja secara bersama-sama berhubungan terhadap kinerja karyawan.

Kepuasan kerja mempengaruhi tingkat kedisiplinan dan kinerja karyawan, artinya jika kepuasan diperoleh dari pekerjaan maka kedisiplinan dan prestasi karyawan baik. Sebaliknya jika kepuasan kerja kurang tercapai dari pekerjaanya maka kedisiplinan dan prestasi karyawan rendah (Hasibuan, 2006:203).

\section{SIMPULAN}

Hasil penelitian ini menunjukkan bahwa variabel kepuasan kerja dan disiplin kerja secara bersama-sama berpengaruh positif terhadap kinerja karyawan Bank Rakyat Indonesia Cabang Putri Hijau Medan. Berdasarkan hasil uji signifikan secara parsial yang paling dominan mempengaruhi kinerja karyawan bagian pemasaran Bank Rakyat Indonesia Cabang Putri Hijau Medan adalah variabel disiplin kerja. Dari hasil analisis koefisien determinasi diperoleh nilai $\mathrm{R}$ Adjusted Square $\left(\mathrm{R}^{2}\right)$ sebesar 0,162 hal ini berarti $16,2 \%$ variabel kinerja dapat dijelaskan oleh variabel kepuasan kerja dan variabel disiplin kerja, sedangkan sisanya sebesar $83,8 \%$ dapat dijelaskan oleh variabel lain yang tidak diteliti dalam penelitian ini seperti sikap kerja, tingkat keahlian, iklim kerja, motivasi, gaya kepemimpinan dan lain sebagainya. Berdasarkan hasil penelitian dan pembahasan, maka penulis dapat memberikan saran sebagai berikut: Bagi Perusahaan, sebaiknya pihak manajemen pemasaran Bank Rakyat Indonesia Cabang Putri Hijau Medan dalam meningkatkan kinerja karyawan bagian pemasaran lebih menitikberatkan pada pemberian balas jasa dan sanksi hukuman, karena variabel disiplin kerja dalam penelitian ini merupakan variabel yang paling dominan berpengaruh terhadap kinerja karyawan. Hendaknya indikatorindikator disiplin kerja; seperti hubungan kemanusiaan dan ketegasan pimpinan yang mempunyai pengaruh signifikan terhadap kinerja karyawan lebih diperhatikan agar dapat memberikan pengaruh yang optimal dalam meningkatkan mutu dan kualitas kerja karyawan, Mengingat bahwa disiplin kerja mempunyai pengaruh positif dan signifikan terhadap kinerja karyawan bagian pemasaran, maka pihak manajemen pemasaran Bank Rakyat Indonesia Cabang Putri Hijau Medan perlu meningkatkan efektifitas disiplin kerja terutama pada aspek hubungan dalam kerja, pemberian teguran pada karyawan yang melanggar peraturan dan pengawasan terhadap karyawan. Bagi 
Peneliti Selanjutnya hasil uji $\left(\mathrm{R}^{2}\right)$ menunjukkan masih ada variabel-variabel lain yang harus diperhatikan dalam penelitian ini. Penelitian-penelitian lebih lanjut, hendaknya menambah variabel lain yang dapat mempengaruhi kinerja karyawan seperti sikap kerja, tingkat keahlian, iklim kerja, motivasi, gaya kepemimpinan dan lain sebagainya, karena dengan semakin baik kinerja karyawan maka akan berpengaruh baik juga bagi perusahaan.

\section{REFERENSI}

Bangun, Wilson, 2012. Manajemen Sumber Daya Manusia, Erlangga, Jakarta.

Fathoni, Abdurahmat, 2006. Manajemen Sumber Daya Manusia, PT. Rineka Cipta, Jakarta.

Gibson, James, L, 2007. Organisasi, Perilaku, Struktur dan Proses, Edisi Kelima, Cetakan Ketiga, Erlangga, Jakarta.

Hasibuan, Malayu S.P, 2006. Manajemen Sumber Daya Manusia, Edisi Revisi,PT Bumi Aksara, Jakarta.

2009. Manajemen Sumber Daya Manusia, Edisi Revisi,PT Bumi Aksara, Jakarta.

Kuncoro, Mudrajad, 2009. Metode Riset untuk Bisnis \& Ekonomi, Erlangga, Jakarta

Mangkunegara, Anwar A.A, 2011. ManajemenSumber Daya Manusia Perusahaan, Edisi Revisi, Cetakan Kesepuluh,PT Remaja Rosdakarya Offset, Bandung.

Musanef, 2002. Manajemen Kepegawaian di Indonesia, Gunung Agung, Jakarta.

Rivai, Veithzal \& Basri, A.F.M, 2005. Performance Apprasial, Raja Grafindo Persada, Jakarta.

Robbins, P. Stephen, 2008. Perilaku Organisasi, Jilid I, Edisi Kedua Belas, Salemba Empat, Jakarta.
Robbins, P. Stephen, 2001. Perilaku Organisasi, Konsep, Kontroversi, Aplikasi, Jilid I, Edisi Kedelapan, Prenhallindo, Jakarta.

Sastrowihadiwiryo, Siswanto, 2002. Manajemen Tenaga Kerja Indonesia,PT Bumi Aksara, Jakarta.

Situmorang, Syafrizal Helmi dan Muslich Lufti, 2011. Analisis Data: Untuk Riset Manajemen dan Bisnis, USU Press, Medan.

Situmorang, Syafrizal Helmi, 2011. Bisnis: Konsep dan Kasus, USU Press, Medan.

Sugiyono, 2006. Metode Penelitian Bisnis,Alfabeta, Bandung.

Sulistiyani, Amar T dan Rosidah, 2003. Manajemen Sumber daya Manusia, Graha Ilmu, Yogyakarta.

Sunyoto, Danang, 2012. Teori, Kuesioner, dan Analisis Data Sumber Daya Manusia, Edisi Revisi, Cetakan Kesepuluh,Center For Academic Publishing Service, Yogyakarta.

Sutrisno, Edy, 2011. Manajemen Sumber Daya Manusia,Kencana, Jakarta.

Tika, Pabundu, 2006. Budaya Organisasi dan Peningkatan Kinerja Perusahaan,PT Bumi Aksara, Jakarta.

Wibowo dan M.Phil, 2007. Manajemen Kinerja, PT.Raja Grafindo Persada, Jakarta.

Wijono, 2011. Psikologi Industri dan Organisasi: Dalam Suatu Bidang Gerak,Kencana Prenada Media Group, Jakarta.

Waridin dan Masrukhin. 2006. "Pengaruh Motivasi Kerja, Kepuasan Kerja, Budaya Organisasi dan Kepemimpinan terhadap Kinerja Pegawai", Jurnal Ekonomi \& Bisnis, Vol. 7, No.2.

Napitupulu. 2011. Pengaruh Disiplin dan Komitmen Karyawan terhadap Prestasi Kerja Karyawan PT. Tonga Tiur Putra Medan. Skripsi Fakultas 


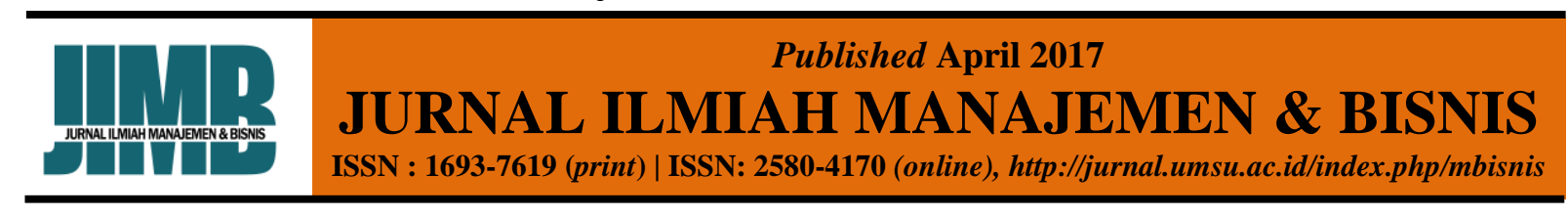

Ekonomi Universitas Sumatera Utara. Medan.

Teruna. 2012. Pengaruh Motivasi dan kepuasan kerja terhadap kinerja karyawan pada PT. Aplikasinusa Lintasarta Medan. Skripsi Fakultas Ekonomi Universitas Muhammadiyah Sumatera Utara. Medan. 